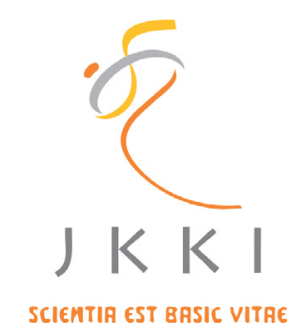

Jurnal Kedokteran dan Kesehatan Indonesia

Indonesian Journal of Medicine and Health

Journal homepage : www.journal.uii.ac.id/index.php/JKKI

\title{
Clinical symptoms and risk factors comparison of ischemic and hemorrhagic Stroke
}

\author{
Rosa De Lima Renita Sanyasi*1, Rizaldy Taslim Pinzon ${ }^{2}$ \\ ${ }^{1}$ Internship Doctor at dr. Efram Harsana Air Force Hospital, Magetan, East Java, Indonesia \\ ${ }^{2}$ Bethesda Hospital, Yogyakarta, Indonesia
}

Original Article

\begin{tabular}{l}
\hline \\
\hline ART IC L E I N F O \\
\hline Keywords: \\
stroke, \\
symptoms, \\
risk factor epidemiology \\
*Corresponding author: \\
rosasanyasi@gmail.com \\
\hline DoI : 10.20885/JKKI.Vol9.Iss1.art3 \\
History: \\
Received: June 26, 2017 \\
Accepted: April 24, 2018 \\
Online: April 30, 2018 \\
\hline
\end{tabular}

Copyright@ @2018 Authors. This is an open access article distributed under the terms of the Creative Commons Attribution-NonCommercial $\quad 4.0$ International Licence (http:// creativecommons.org/licences/ by-nc/4.0/).

\section{ABSTRACT}

Backround: It is very important to know and detect various stroke symptoms because stroke is an emergency condition. Lack of knowledge about stroke symptoms leads to delay on stroke treatment.

Objective: The aim of this study is to compare clinical symptoms and risk factors between ischemic and hemorrhagic stroke.

Methods: This study was a case control study. The subjects in this study were ischemic and hemorrhagic stroke patients. Subjects' data were recorded in electronic stroke registry at Bethesda Hospital, Yogyakarta.

Results: The most common clinical symptoms in both groups were limb weakness $(76.4 \%$ vs $71.4 \%)$, whereas the rarest was face drooping $(2 \%$ vs $3.6 \%)$. Hypertension was the most common risk factor in both group ( $48 \%$ vs $71.4 \%$ ), whereas atrial fibrillation was the rarest. This study did not find the specific correlation between any clinical symptoms to ischemic stroke incidence, however, decrease a level of consciousness was significant to hemorrhagic stroke incidence (OR: 2.738, 95\% CI: 1.503-4.990, p: 0.001). Previous stroke (OR: 2.413, 95\% CI: 1.314-4.433, p: 0.005 ) and dyslipidemia (OR: 4.862, 95\% CI: 2.613-9.045, p: 0.000) were significant increasing risk of ischemic stroke. Hypertension was only the significant increasing risk of hemorrhagic stroke (OR: 3.680, 95\% CI: 2.086-6.492, p: 0.000).

Conclusion: Decrease level of consciousness has a significant correlation to hemorrhagic stroke incidence, but there is no specific symptom correlate to ischemic stroke incidence. Previous stroke and dyslipidemia are significant risk factors for ischemic stroke, whereas hypertension is the only significant risk factor for hemorrhagic stroke.

Latar Belakang: Sangat penting untuk mengetahui dan mendeteksi gejala stroke dengan segera karena penanganan stroke berpacu dengan waktu. Kurangnya pengetahuan mengenai gejala stroke akan mengakibatkan keterlambatan dalam penanganan stroke.

Tujuan Penelitian: Penelitian ini bertujuan untuk mengetahui perbandingan gejala klinis dan faktor risiko pada pasien stroke iskemik dan stroke hemoragik.

Metode: Penelitian ini menggunakan desain penelitian kasus kontrol. Subjek dalam penelitian ini adalah pasien stroke iskemik dan stroke hemoragik yang tergister elekronik di Rumah Sakit Bethesda, Yogyakarta. Hasil: Gejala klinis yang paling sering muncul pada kedua grup adalah kelemahan anggota gerak $(76.4 \%$ vs $71.4 \%$ ), sedangkan gejala klinis yang paling jarang adalah wajah perot (2\% vs 3.6\%). Hipertensi merupakan faktor risiko stroke yang paling sering dijumpai pada kedua grup (48\% vs $71.4 \%$ ), sedangkan atrial fibrilasi paling jarang dijumpai. Penelitian ini tidak menemukan adanya gejala khusus yang 
berkorelasi dengan stroke iskemik, sedangkan gejala penurunan kesadaran signifikan berkorelasi dengan stroke hemoragik (OR: 2.738, 95\% CI: 1.503-4.990, p:0.001). Riwayat stroke sebelumnya (OR: 2.413, 95\% CI: 1.314-4.433, p: 0.005) dan dislipidemia (OR: 4.862, 95\% CI: 2.613-9.045, p: 0.000) signifikan meningkatkan risiko stroke iskemik. Hipertensi signifikan meningkatkan risiko stroke hemoragik (OR: 3.680, 95\% CI: 2.086-6.492, p: 0.000).

Kesimpulan: Penurunan kesadaran merupakan gejala yang berkaitan erat dengan kejadian stroke hemoragik, namun tidak ditemukan gejala yang spesifik berkorelasi dengan kejadian stroke iskemik. Riwayat stroke sebelumnya dan dislipidemia merupakan dua faktor risiko yang signifikan dalam meningkatkan risiko stroke iskemik, sedangkan hipertensi merupakan satu-satunya faktor risiko yang secara signifikan meningkatkan risiko stroke hemoragik.

\section{INTRODUCTION}

Non-communicable diseases (NCDs) kill 38 million ( $68 \%$ of total deaths worldwide) people per year. ${ }^{1}$ Cardiovascular disease, which includes coronary heart disease and stroke, is the largest NCDs, followed by cancer, disease chronic respiration, and diabetes mellitus. ${ }^{1,2}$ Stroke is a major cause of disability and death in some countries, such as in China, Japan, and western countries. ${ }^{3,45}$ The prevalence of stroke in Indonesia, according to the diagnosis of health workers, noted in Basic Health Research (Riskesdas) 2013 was as much as $7.0 \%$, whereas according to the diagnosis of health personnel or symptoms was as much as $12.1 \%$. This figure increased when compared with Riskesdas in 2007 that was as much as $8,3 \%{ }^{2}{ }^{2}$

Patient recognition of stroke symptom is very important because time is of the essence for treating a stroke. ${ }^{6,7}$ A study conducted in 163 patients showed that about $40 \%$ of patients did not know the signs and symptoms of stroke. ${ }^{1}$ Lack of knowledge about the symptoms of stroke will result in delays in the treatment of stroke. ${ }^{8}$ More than half of the patients (57.7\%) admitted to seeking help to the hospital within the first 24 hours and only about $37.4 \%$ of patients admitted to the hospital within 6 hours post- onset of attack. ${ }^{9}$ A study conducted by Haryanti, et al. (2015) of 101 stroke patients in Malang showed that $18.7 \%$ of stroke patients arrived at the hospital within 3 hours, while the rest arrived after $>3$ hours post-onset..$^{10} A$ study in Japan revealed that providing information about early stroke symptoms periodically can increase people's knowledge significantly. ${ }^{11}$

Stroke risk factors can be classified into two types, modifiable and unmodifiable risk factors. Unmodifiable risk factors include age, gender, race, and family history. ${ }^{12,13}$ Hypertension, diabetes mellitus, dyslipidemia, heart disease, physical inactivity, smoking, and obesity are included in modifiable risk factors. ${ }^{14}$ Modifiable risk factors are often regarded as an opportunity for interventions to reduce the risk of stroke..$^{15}$ Knowledge about various stroke risk factors will be useful to reduce the risk of stroke in an asymptomatic person (primary prevention) as well as to prevent recurrence of stroke in patients with a history previous stroke (secondary prevention). ${ }^{16}$

This study is expected to provide updated information on various clinical symptoms and risk factors for stroke. Proper understanding about the clinical symptoms that often appear in stroke patients is very important to accelerate early detection so that patients can get immediate treatment, while information on risk factors is useful to prevent stroke and reduce morbidity and mortality caused by stroke. Socialization to the general public about both should be done to increase public awareness of stroke. ${ }^{17}$ The purpose of this study is to determine the comparison of clinical symptoms and risk factors in ischemic stroke with hemorrhagic stroke. The results obtained are expected to be useful to distinguish the type of stroke when investigation cannot be done.

\section{METHODS}

This was a case-control study which was conducted from March 2017 to June 2017. Cases were the subjects with diagnosed with stroke Because our objective was to compare the clinical symptoms and risk factors in ischemic 
and hemorrhagic stroke, there was 2 groups in this study. The group 1 consisted of subjects with ischemic stroke as a case group and subjects with hemorrhagic stroke as a control group. The group 2 consisted of subjects with hemorrhagic strokes as a case group and subjects with ischemic stroke as a control group. In order to avoid bias, the data used as a control group was taken from a different year from the case group. Any duplicate data will be excluded.

The inclusion criteria for the case groups include: (i) Patients diagnosed with ischemic stroke or hemorrhagic stroke, confirmed by full physical neurological examination and examination with computed tomography (CT) Scan, (ii) Underwent inpatient at Bethesda Hospital, Yogyakarta between 2013 and 2016, and (iii) Subject data recorded in electronic stroke register at Bethesda Hospital, Yogyakarta. The control group inclusion criteria were (i) Patients diagnosed with ischemic stroke or hemorrhagic stroke confirmed by complete neurological examination and computed tomography (CT) scan, (ii) Underwent hospitalization at Bethesda Hospital, Yogyakarta between 2009 and 2012 and (iii) Subject's data was well-recorded in electronic stroke register at Bethesda Hospital, Yogyakarta. Research subjects with Transient Ischemic Attack (TIA), having intracranial hemorrhage due to trauma or having incomplete data will be excluded from this study.

Stroke in this study was defined as a focal or global acute neurological disorder caused by vascular disorders and persisted for more than 24 hours or to cause death. ${ }^{18,19}$ Ischemic stroke in this study was determined using the Trial of ORG 10172 in Acute Stroke Treatment (TOAST classification) as references, which include: (1) large blood vessel atherosclerosis, (2) cardioembolic, (3) lacunar, (4) stroke with other causes, and (5) stroke with unclear cause. ${ }^{20,21}$ Hemorrhagic Stroke in this study included intracerebral hemorrhage and subarachnoid hemorrhage.

Subject data that were taken include age, gender, clinical symptoms, and stroke risk factors. The prevalence of stroke increases with age. Previous studies have shown an average age of stroke patients around 60 years old. ${ }^{22-25}$ Therefore, in this study age was differentiated to $\geq 60$ years and $<60$ years. Clinical symptoms of recorded stroke included: decreased consciousness, aphasia, limb weakness, dysarthria, and facial asymmetry. The recorded clinical symptoms were the dominant symptoms seen at admission. Stroke risk factors that were examined include age, gender, previous history of stroke, hypertension, type 2 diabetes mellitus, dyslipidemia, ischemic heart disease, and atrial fibrillation.

Decreased of consciousness in this study included somnolent, stupor, coma, or delirium that arose suddenly, concluded through physical examination and neurological examination. Aphasia was defined as the inability to communicate, either in speech or incomprehension of speech and/or writing, arising suddenly. The limb weakness in this study was defined as the inability to move the limbs that arise suddenly and assessed by examination of motor strength. Dysarthria was defined as the inability to speak the words clearly that arise suddenly. Facial asymmetry was defined as an asymmetric facial expression arising suddenly and assessed by examination of the cranial nerves.

Stroke risk factors assessed in this study included: age, gender, previous stroke history, hypertension, type 2 diabetes mellitus (DM2), dyslipidemia, ischemic heart disease (IHD), and atrial fibrillation (AF). Hypertension criteria used in this study was of JNC 7, which mean someone who has systolic blood pressure $\geq 140$ mmHg or diastolic blood pressure $\geq 90 \mathrm{mmHg}$. Subjects who took antihypertensive drugs and had normal blood pressure was still classified as hypertension. DM2 was defined as a blood sugar level $\geq 200 \mathrm{mg} / \mathrm{dL}$ with classical symptoms of hyperglycemia (polydipsia, polyuria, polyphagia), or fasting blood glucose $\geq 126 \mathrm{mg} / \mathrm{dL}$, or 2 hours postprandial $\geq 200 \mathrm{mg} / \mathrm{dL}$, or $\mathrm{A} 1 \mathrm{C} \geq 6.5 \%$. Any subjects who took regular antidiabetic and/or insulin drugs with normal blood sugar levels were classified as patients with DM2. Subjects 
were classified as people with dyslipidemia if they had cholesterol lipoprotein $\geq 140 \mathrm{mg} / \mathrm{dL}$, high density lipoprotein $<40 \mathrm{mg} / \mathrm{dL}$, triglycerides $>$ $200 \mathrm{mg} / \mathrm{dL}$ and/ or total cholesterol $>200 \mathrm{mg} /$ dL. Subjects who consumed regular blood lipidlowering drugs with normal lipid profile were classified as people with dyslipidemia. Ischemic heart disease in this study included unstable angina pectoris, ST-STI and STEMI, confirmed by electrocardiographic (EKG) examination. AF was defined as an irregular heart rhythm and confirmed by an EKG examination.

In total there were 4500 subjects included in the case group and 2020 subjects in the control group. A total of 51 subjects were excluded from the case group and 129 subjects were excluded from the control group because the data were incomplete. The remaining 4449 subjects in the case group consisted of 3455 subjects with ischemic stroke and 994 subjects with hemorrhagic stroke. In the control group, the remaining 1891 subjects consisted of 1390 subjects with ischemic stroke and 501 subjects with hemorrhagic stroke. The comparison of the number of subjects in the case group and control group was 1 in 1 (1:1). After the calculation of the number of samples, there were 296 subjects in group 1 and 280 subjects in group 2 .

Research subjects were taken with a simple random sampling method. Bivariate analysis was done using Chi-square test while multivariate analysis used logistic regression. The significance level between variables was expressed by the odd ratio (OR) with 95\% confidence interval and $\mathrm{p}$-value $<0.05$

This research has been approved by medical research ethic committee of Fakultas Kedokteran Universitas Kristen Duta Wacana article number 418/C.16/FK/2017.

\section{RESULTS}

There were 296 subjects in group 1 and 280 subjects in group 2. Case group in group 1 was the ischemic stroke, while in group 2 was the hemorrhagic stroke. Group 1 is dominated by age $\geq 60$ years $(56.1 \%)$, whereas in group 2 it is dominated by age $<60$ years $(51.4 \%)$. Both groups were dominated by male gender $(58.1 \%$ vs $61.4 \%)$. The most common clinical symptoms in both groups were limb weakness $(76.4 \%$ vs $71.4 \%)$, whereas rarest clinical symptoms were facial asymmetry ( $2 \%$ vs $3.6 \%$ ). Hypertension is the most common risk factor for stroke in both groups ( $48 \%$ vs $71.4 \%$ ).

Each variable listed in Table 1 was analyzed using bivariate and multivariate analyzes. Table 2 shows the results of the bivariate analysis. Decreased consciousness was the only significant symptom of ischemic stroke (p: 0.000), whereas in hemorrhagic stroke there were 2 significant symptoms, which were decreased of consciousness (p: 0.000) and dysarthria (p: 0.003 ). The previous history of stroke was one of the major risk factors for ischemic stroke (p: 0.035). Hypertension, DM2, and dyslipidemia were significant risk factors for both ischemic and hemorrhagic stroke.

Significant results in bivariate analysis were further analyzed using logistic regression. The previous history of stroke increased the risk of ischemic stroke by 2,413-fold (95\% CI: $1.314-$ 4.433, p: 0.005), whereas dyslipidemia increased the risk of ischemic stroke by 4,862 -fold (95\% CI: 2,613-9,045, p: 0.000). No specific symptoms were found to be correlated with ischemic stroke.

Table 4 reveals the results of logistic regression analysis in group 2 . The decrease of consciousness is significantly correlated with hemorrhagic stroke (OR: 2.738, 95\% CI: 1.5034.990, p: 0.001). Hypertension increases the risk of hemorrhagic stroke by 3,680-fold (95\% CI: 2.086-6.492, p: 0.000). 
Table 1. Subject Basic Characteristic

\begin{tabular}{|c|c|c|c|c|c|}
\hline & \multirow{3}{*}{ Characteristics } & \multicolumn{4}{|c|}{ Case Group } \\
\hline & & \multicolumn{2}{|c|}{ Stroke Ischemic $(n=148)$} & \multicolumn{2}{|c|}{ Stroke Hemmorhagic $(n=140)$} \\
\hline & & Total & Percentage & Total & Percentage \\
\hline \multirow[t]{2}{*}{ Age } & $\geq 60$ years old & 83 & $56.1 \%$ & 68 & $48.6 \%$ \\
\hline & $<60$ years old & 65 & $45.5 \%$ & 72 & $51.4 \%$ \\
\hline \multirow[t]{2}{*}{ Gender } & Male & 86 & $58.1 \%$ & 86 & $61.4 \%$ \\
\hline & Female & 62 & $41.9 \%$ & 54 & $38.6 \%$ \\
\hline \multirow[t]{5}{*}{ Symptoms } & Decrease consciousness & 32 & $21.6 \%$ & 62 & $44.3 \%$ \\
\hline & Aphasia & 32 & $21.6 \%$ & 31 & $22.1 \%$ \\
\hline & Limb weakness & 113 & $76.4 \%$ & 100 & $71.4 \%$ \\
\hline & Dysarthria & 41 & $27.7 \%$ & 19 & $13.6 \%$ \\
\hline & Facial assimmetry & 3 & $2 \%$ & 5 & $3.6 \%$ \\
\hline \multirow[t]{6}{*}{ Risk factors } & Previous history of stroke & 47 & $31.8 \%$ & 31 & $22.1 \%$ \\
\hline & Hypertension & 71 & $48 \%$ & 100 & $71.4 \%$ \\
\hline & DM2 & 32 & $21.6 \%$ & 13 & $9.3 \%$ \\
\hline & Dyslipidemia & 64 & $43.2 \%$ & 16 & $11.4 \%$ \\
\hline & IHD & 8 & $5.4 \%$ & 9 & $6.4 \%$ \\
\hline & $\mathrm{AF}$ & 5 & $3.4 \%$ & 2 & $1.4 \%$ \\
\hline
\end{tabular}

DM2: Diabetes Mellitus type 2, IHD: Ischemic Heart Disease, AF: Atrial Fibrilation

Table 2. Bivariate analysis

\begin{tabular}{llcccccc}
\hline \multicolumn{1}{l}{ Characteristics } & \multicolumn{3}{c}{ Group 1 } & \multicolumn{3}{c}{ Group 2 } \\
& & $\mathbf{0 R}$ & $\mathbf{9 5 \%} \mathbf{~ C I}$ & $\mathbf{p}$ & $\mathbf{0 R}$ & $\mathbf{9 5 \%}$ CI & P \\
\hline \multirow{2}{*}{ Symptoms } & Decrease consciousness & 0.299 & $0.180-0.497$ & 0.000 & 3.485 & $2.029-5.986$ & 0.000 \\
& Aphasia & - & - & 0.302 & - & - & 0.458 \\
& Limb weakness & - & - & 0.071 & - & - & 0.069 \\
& Dysarthria & - & - & 0.425 & 0.407 & $0.221-0.747$ & 0.003 \\
& Facial assimmetry & - & - & 0.652 & - & - & 0.473 \\
Risk Factors & Age $\geq 60$ tahun & - & - & 0.131 & - & - & 0.633 \\
& Male gender & - & - & 0.293 & - & - & 0.714 \\
& Previous history of stroke & 1.756 & $1.038-2.971$ & 0.035 & - & - & 0.885 \\
& Hypertension & 0.275 & $0.167-0.454$ & 0.000 & 2.803 & $1.709-4.596$ & 0.000 \\
DM2 & 1.992 & $1.062-3.739$ & 0.030 & 0.471 & $0.230-0.964$ & 0.036 \\
Dyslipidemia & 3.749 & $2.186-6.427$ & 0.000 & 0.194 & $0.104-0.360$ & 0.000 \\
IHD & - & - & 0.238 & - & - & 0.156 \\
AF & - & - & 0.473 & - & - & 0.409 \\
\hline
\end{tabular}

OR: Odd Ratio, CI: Confidence Interval, DM2: Diabetes Mellitus type 2, IHD: Ischemic Heart Disease, AF: Atrial Fibrilation 
Table 3. Group 1 logistic regression analysis

\begin{tabular}{llccc}
\hline & Characteristic & OR & $\mathbf{9 5 \%}$ CI & P \\
\hline Symptoms & Decrease consciousness & 0.315 & $0.177-0.559$ & 0.000 \\
Risk Factors & Previous stroke history & 2.413 & $1.314-4.433$ & 0.005 \\
& Hypertension & 0.187 & $0.104-0.336$ & 0.000 \\
& DM2 & - & - & 0.085 \\
& Dyslipidemia & 4.862 & $2.613-9.045$ & 0.000 \\
\hline
\end{tabular}

OR: Odd Ratio; CI: confidence interval, DM2: diabetes mellitus type 2, IHD: ischemic heart disease, AF: atrial fibrilation

Table 4. Group 2 logistic regression analysis

\begin{tabular}{llccc}
\hline & Characteristic & OR & $\mathbf{9 5 \%}$ CI & P \\
\hline Symptoms & Decrease consciousness & 2.738 & $1.503-4.990$ & 0.001 \\
& Dysarthria & 0.468 & $0.236-0.927$ & 0.029 \\
Risk Factors & Hypertension & 3.680 & $2.086-6.492$ & 0.000 \\
& DM2 & - & - & 0.064 \\
& Dyslipidemia & 0.194 & $0.104-0.360$ & 0.000 \\
\hline
\end{tabular}

OR: Odd Ratio; CI: confidence interval, DM2: diabetes mellitus type 2, IHD: ischemic heart disease, AF: atrial fibrilation

\section{DISCUSSION}

The population in this study was dominated by ischemic stroke, which was conducted by 3455 ischemic stroke patients in the case group and 1390 in the control group. Various other studies also showed similar results. The prevalence and incidence of ischemic stroke are greater than hemorrhagic stroke. A previous study by Shiber, et al. (2010) conducted with 757 stroke patients, showed $58.1 \%$ of its subjects were patients with ischemic stroke, whereas the remaining $41.9 \%$ were patients with hemorrhagic stroke. ${ }^{26}$ Percentages in another study showed much greater differences, in which $87.5 \%$ of subjects had ischemic stroke and $14.3 \%$ subjects had hemorrhagic stroke. ${ }^{27}$

Subjects with ischemic stroke were predominantly $\geq 60$ years old ( $56.1 \%$ ), whereas most subjects with hemorrhagic stroke were < 60 years old $(51.4 \%)$. The incidence of stroke increased with age. ${ }^{15}$ The results of bivariate and multivariate analyzes in this study showed that the age of $\geq 60$ years did not significantly increase the risk of stroke, both ischemic and haemorrhagic. These results contradict previous studies suggesting that advanced age increases the risk of stroke. ${ }^{28,29}$ The difference in outcomes is probably caused by the age classification used in this study, that was conducted in dichotomies ( $\geq 60$ years and $<60$ years), whereas other studies used various stratifications of the age group for their analysis.

The subjects of this study were dominated by male (58.1\% vs $61.4 \%$ ) both in subjects with ischemic stroke and hemorrhagic stroke. Males are the more vulnerable to stroke. According to Samai and Martin (2015), the incidence of stroke is 1.25 -fold higher in men. ${ }^{30}$ Another study showed that men were 1.5 times more likely to have a stroke than women ( $4.53 \%$ vs $2.91 \%$, p $<0.05) .{ }^{31}$ However, in this study, no significant results were found between male gender and stroke. This result is in accordance with a study by Copstein et al. (2013) in Brazil who found gender is not significantly correlated with stroke, when compared to subjects without stroke. ${ }^{32}$

Five clinical symptoms were analyzed in this study, as follow: decrease of consciousness, aphasia, limb weakness, dysarthria, and facial asymmetry. The most commonly found symptoms in subjects with ischemic stroke is limb weakness (76.4\% vs $71.4 \%)$. This result is in 
accordance with the previous study, in which arm weakness (63\%) and leg weakness (54\%) were also found as the most commonly complained symptoms. ${ }^{33}$ A study by Ghaendehari et al. (2007) in 1392 stroke patients in Iran showed 79\% stroke cases were manifested as limb weakness. ${ }^{34}$

The results of interviews with 112 research subjects conducted by Hariyanti et al. (2015) states that hemipareses are the most common symptom (57.4\%). ${ }^{10}$ Symptoms of limb weakness in stroke patients vary, it can be in the form of hemiparesis or monoparesis. A research by Paciaroni et al. (2005) stated that 51 stroke patients had symptoms of monoparesis, 39 of them had the ischemic stroke and the remaining 12 had the hemorrhagic stroke. ${ }^{35}$ Monoparesis as one of the symptoms of stroke is still rarely known. The ability to recognize monoparesis as a symptom of stroke is very important to start stroke treatment as early as possible. ${ }^{36}$

Decreased consciousness is the second symptom that often appears on the subject with hemorrhagic stroke (44.3\%), whereas in the subject with ischemic stroke the symptoms appear only as much as $21.6 \%$. In bivariate analysis, this symptom significantly correlated with ischemic stroke or hemorrhagic stroke. However, multivariate analysis showed that decrease of consciousness is only significant to hemorrhagic stroke (OR: 2.738, 95\% CI: 1.5034.990, p: 0.001). Decreased of consciousness often encourage people to seek immediate medical help. ${ }^{37}$ Low GCS scores affect significantly on the prevalence of hemorrhagic stroke $(\mathrm{p}$ $<0.001) .{ }^{38}$ Previous studies have shown that loss-consciousness is more common in patients with intracerebral hemorrhage compared with ischemic stroke due to increased intracranial pressure and compression of the thalamus and medulla oblongata. ${ }^{27,33,37,39}$

There are two symptoms of communication disorders identified in this study, which are aphasia and dysarthria. Aphasia was found more common in subjects with hemorrhagic stroke than ischemic stroke ( $22.1 \%$ vs. $21.6 \%$ ). This is in accordance with a previous study by Krishnan et al. (2012) which states that aphasia appears in 8 of 12 hemorrhagic stroke patients. ${ }^{40}$ There are different types of aphasia that can occur in stroke patients. Broca aphasia (33.3\%), global aphasia (29.2\%) and anomic aphasia (20.8\%) are the most commonly found type of aphasia in stroke patients. ${ }^{41}$ In this study, aphasia was found to be insignificant to neither type of stroke.

In this study, dysarthria was found more frequently in subjects with ischemic stroke than hemorrhagic stroke (27.7\% vs. $13.6 \%)$. A previous study by Shigematsu, et al. (2013) in 1,693 cases of ischemic stroke in Japan showed that speech impairment was seen in $52.5 \%$ cases. ${ }^{42}$ Dysarthria is a symptom of ischemic stroke that often arises from a disturbance in the posterior circulation. ${ }^{43}$ In bivariate analysis, dysarthria was found as a significant symptom of hemorrhagic stroke, but the further analysis did not show any significant correlation.

Facial asymmetry is rarest symptom in this study, both in subjects with ischemic stroke (2\%) and hemorrhagic stroke (3.6\%). This is in accordance with a previous research by Magistris et al. (2013), which states that facial muscle weakness is rarest symptom when compared with the weakness of limbs and communication disorders. ${ }^{33}$ Similarly, Lisabeth et al. (2009) stated that facial muscle weakness is rarest symptoms when compared with the limb weakness, decreased of consciousness, aphasia, and dysarthria. ${ }^{43}$

In this study, previous history of stroke (p: 0.035), hypertension (p: 0.000), DM2 (p: 0.030 ), and dyslipidemia (p: 0.000 ) were found as significant risk factors in ischemic stroke based on the bivariate analysis. After further analysis, only prior history of stroke (OR: 2,413 , 95\% CI: 1,314-4,433, p: 0.005) and dyslipidemia (OR: 4.862, 95\% CI: 2,613-9,045, p: 0.000) were found as significant risk factors for ischemic stroke. The results of this study are in accordance with previous studies. Approximately $25 \%$ of total stroke cases are recurrentstrokes and its mortality rate is $41 \%{ }^{44}$ Previous history of stroke is more common in ischemic stroke than in hemorrhagic stroke. ${ }^{45}$

A research by Alpha-Tocopherol, Beta- 
Carotene Cancer Prevention Study showed an increased risk of ischemic stroke by 1.25 -fold at total cholesterol levels $\geq 271 \mathrm{mg} / \mathrm{dL}$. A study of 352,033 Asian and New Zealand residents conducted by the asia pacific cohort studies collaboration showed an increased risk of ischemic stroke by $25 \%$ for each $1 \mathrm{mmol} / \mathrm{L}$ increase in total cholesterol levels. The same results are shown by the women's pooling project study which states that high total cholesterol levels are associated with an increased risk of ischemic stroke. ${ }^{46}$

This study showed that hypertension increased the risk of hemorrhagic stroke by 3,680-fold (95\% CI: 2.086-6.492, p: 0.000). This result is consistent with the statement of Keep et al. (2012), which stated that hypertension is the most important risk factor in the incidence of hemorrhagic stroke. ${ }^{47}$ The incidence of hemorrhagic stroke will increase with increasing blood pressure. ${ }^{48}$ Arboix (2015) mentioned that a person with hypertension has a risk of intracerebral hemorrhage 3.9 times higher and subarachnoid hemorrhage 2,8 times higher than a person with normotension. ${ }^{49}$ If blood pressure reaches $>160 / 90 \mathrm{mmHg}$, the risk of hemorrhagic stroke will increase 7-fold when compared with people with normotension. ${ }^{50}$ Hypertension also increases the risk of recurrent intracerebral hemorrhage. ${ }^{51}$

IHD (5.4\% vs $6.4 \%)$ and AF (3.4\% vs $1.4 \%$ ) are two rare risk factors in both groups. These two factors are known to induce ischemic stroke more, however, this study did not found significant. ${ }^{52,53}$ It might be because the subjects presented with these conditions were too small. Further research regarding the correlation of IHD and AF to stroke is needed.

\section{CONCLUSION}

There are a variety of symptoms that can occur in stroke patients, including weakness of limbs, decreased consciousness, aphasia, dysarthria, and facial asymmetry. This study found that the most frequent clinical symptom in patients with ischemic stroke or hemorrhagic stroke is limb weakness, whereas the least common symptom is facial asymmetry. Hypertension is the most common risk factor for stroke, whereas atrial fibrillation is the least common risk factor. Decreased consciousness is a symptom that is closely related to the incidence of hemorrhagic stroke, but no symptoms are correlated closely with the incidence of ischemic stroke. The previous history of stroke and dyslipidemia are two significant risk factors in increasing the risk of ischemic stroke, whereas hypertension is the only risk factor that significantly increases the risk of hemorrhagic stroke.

\section{CONFLICT OF INTEREST}

We declare there is no conflict of interest

\section{ACKNOWLEDGEMENT}

Non declare

\section{REFERENCES}

1. Mozaffarian D, Benjamin EJ, Go AS, Arnett DK Blaha MJ Cushman M, et al. Heart disease and stroke statistics-2015 update: A report from the American Heart Association. Circulation. 2015;131:e29-e322.

2. Badan Penelitian dan Pengembangan Kesehatan (Banglitbangkes). Riset kesehatan dasar Tahun 2013 [Internet]. Kementerian Kesehatan RI. 2013. Available from: http:// labdata.litbang.depkes.go.id/ riset-badanlitbangkes/menu-riskesnas/ menu-riskesdas/374-rkd-2013

3. Zhou M, Offer A, Yang G, Smith M, Hui G, Whitlock G, et al. Body mass index, blood pressure, and mortality from stroke: A nationally representative prospective study of 212.000 Chinese men. Stroke. 2008;39:753-9.

4. Toyoda K. Epidemiology and registry studies of stroke in Japan. The Journal of Stroke. 2013;15(1):21-6.

5. do Carmo JF, Morelato RL, Pinto HP, de Oliveira ERA. Disability after stroke: A systematic review. Physical Therapy in Movement. 2015;28(2):407-18.

6. Walter S, Schlechtriemen T, Kostpopoulos P, Haass A, Helwig S, Keller I, et al. Bringing the hospital to the patient: First treatment 
of stroke patients at the emergency site. PLoS ONE. 2011;5(10):e13758.

7. Musuka TD, Wilton SB, Traboulsi M, Hill MD. Diagnosis and management of acute ischemic stroke: Speed is critical. Canadian Medical Association Journal. 2015;187(12):887-93.

8. Mellor RM, Bailey S, Sheppard J, Carr P, Quinn T, Boyal A, et al. Decision and delays within stroke patients' route to the hospital: A qualitative study. Annals of Emergency Medicine. 2015;65(3):279-87.

9. Assogba K, Mofou B, Ekué AF, Apetse KM, Kombate D, Ekouevi KD. Epidemiology, risk factor, type and outcome of stroke in health care facilities of Lomé, Togo: A prospective study. The Southern Journal of Philosophy. 2015;3(1):25-30.

10. Hariyanti T, Harsono, Yayi S. Health seeking behaviour on stroke patients. Jurnal Kedokteran Brawijaya. 2015;28(3):242-6.

11. Morimoto A, Miyamatsu N, Okamura T, Nakayama H, Toyoda K, Suzuki K, et al. Effects of intensive and moderate public education on knowledge of early stroke symptoms among a Japanese population the acquisition of stroke knowledge study. Stroke. 2013;44:2829-34.

12. Choudhury JH, Chowdhury TI, Nayeem A, Jahan WA. Modifiable and non-modifiable risk factors of stroke: A review update. Journal of National Institute of Neurosciences Bangladesh. 2015;1(1):22-6.

13. Atri A, Milligan TA. Ischemic stroke: Evaluation, treatment, and prevention. Neurology. 2009;13(2):1-16.

14. Roger VL, Jones DML, Benjamin EJ, Berry JD, Borden WB, Bravata DM. Heart disease and stroke statistics-2012 update. Circulation. 2012;125(1):e1-220.

15. Ovbiagele B, Nguyen-Huynh MN. Stroke epidemiology: Advancing our understanding of disease mechanism and therapy. Neurotherapeutics. 2011;8:319-29.

16. Ringleb PA, Bousser MG, Bath P, Brainin M, Caso, Cervera A, et al. Ischaemic stroke and transient ischaemic attack. In: European Handbook of Neurological Management Volume 1, 2nd Edition. UK: Blackwell Pu- bishing Ltd; 2011. p. 112-8.

17. Jauch EC, Saver JL, Adams HP, Bruno A, Connors JJ, Demaerschalk BM, et al. Guidelines for the early management of patients with acute ischemic stroke a guideline for healthcare professionals from the American Heart Association/American Stroke Association. Stroke. 2013;44:870-947.

18. Sacco RL, Kasner SE, Broderick JP, Caplan LR, Connors JJ, Culebras A, et al. An update definition of stroke for the 21st century. Stroke. 2013;44:2064-89.

19. Mahmood A, Sharif MA, Khan MN, Ali UZ. Comparison of serum lipid profile in ischaemic and haemorrhagic stroke. Journal of the College of Physicians and Surgeons--Pakistan. 2010;20(5):317-20.

20. Varona J, Guerra J, Bermejo F, Molina JA, Gomez de la Camara A. Causes of ischemic stroke in young adults, and evolution of the etiological diagnosis over the long term. European neurology. 2007;57:212-8.

21. Varona JP. Diagnostic work-up and etiology in ischemic stroke in young adults before and now. Journal of Neurology and Neurophysiology. 2012;3:133.

22. Miah MNA, Azhar MA, Rahman A, Halder D, Akteruzzaman M, Kundu NC. Risk factors of stroke in young and old age group - A comparative study. Bangladesh Journal of Medicine. 2012;13:138-42.

23. Rathore JA, Kango ZA, Nazir M, Mehraj. Risk factors for stroke: A prospective hospital based study. Journal of Ayub Medical College Abbottabad [Internet]. 2013;25:1-2. Available from: https://www.ncbi.nlm.nih. gov/pubmed/25098044

24. Bhatt VR, Parajuli N, Mainali NR, Sigdel SM, Aryal M, Hamal N, et al. Risk factors of stroke. Journal of Institute of Medicine. 2008;30(3):37-41.

25. Park TH, Ko Y, Lee SJ, Lee KB, Lee J, Han $\mathrm{MK}$, et al. Identifying target risk factors using population attributable risks of ischemic stroke by age and sex. The Journal of Stroke. 2015;17(3):302-11.

26. Shiber JR, Fontane E, Adewale A. Stroke registry: Hemorrhagic vs ischemic strokes. American Journal of Emergency Medicine. 
2010;28:331-33.

27. Aksoy D, Ayan M, Alatlı T, Şahin F, Özdemir MB, Çevik B, et al. Clinical and demographic properties of the acute stroke patients admitted to emergency department of a tertiary referral center. Journal of Applied \& Environmental Microbiology. 2014;13:135-8.

28. Zhang S, Liu Z, Liu YL, Wang YL, Liu T, Cui $\mathrm{XB}$. Prevalence of stroke and associated risk factors among middle-aged and older farmers in Western China. Environmental Health and Preventive Medicine. 2017;22(1):1-6.

29. Nacu A, Fromm A, Sand KM, Waje-Andreassen U, Thomassen L, Naess H. Age dependency of ischaemic stroke subtypes and vascular risk factors in western Norway: The bergen Norwegian stroke cooperation study. Acta Neurologica Scandinavica. 2016;133(3):202- 07.

30. Samai AA, Martin-Schild S. Sex differences in predictors of ischemic stroke: Current perspectives. Vascular Health and Risk Management. 2015;11:427-36.

31. Venketasubramanian N, Tan L, Sahadevan S. Prevalence of stroke among Chinese, Malay, and Indian Singaporeans: A community-based tri-racial cross-sectional survey. Stroke. 2005;36:551-6.

32. Copstein L, Fernandes JG, Bastos GAN. Prevalence and risk factors for stroke in a population of Southern Brazil. Arquivos de Neuro-Psiquiatria. 2013;71(5):294-300.

33. Magistris F, Bazak S, Martin J. Intracerebral hemorrhage: Pathophysiology, diagnosis and management. McMaster University Medical Journal. 2013;10(1):15-9.

34. Ghandehari K, Mood ZI. Khorasan stroke registry: Analysis of 1392 stroke patients. Archives of Iranian medicine. 2007;10(3):327-34.

35. Paciaroni M, Caso V, Milia P, Venti M, Silvestrelli Palmerini $\mathrm{F}$, et al. Isolated monoparesis following stroke. Journal of Neurology, Neurosurgery, and Psychiatry. 2005;76(6):805-07.

36. Eboli P, Moheet A, Song S, Ryana R, Alexandera M. Hand monoparesis due to small cortical ischemic stroke, etiology, prognosis and medical management: Case report and literature review. Journal of Medical Cases. 2013;4(6):429-32.

37. Broderick J, Connolly S, Feldmann E, Hanley D, Kase C, Krieger D, et al. Guidelines for the management of spontaneous intracerebral hemorrhage in adults: 2007 update: A guideline from the American Heart Association/American Stroke Association Stroke Council, High Blood Pressure Research Council, and the Quality of Care and Out. Stroke. 2007;116(6):e391-413.

38. Ojaghihaghighi S, Vahdati SS, Mikaeilpour A, Ramouz A. Comparison of neurological clinical manifestation in patients with hemorrhagic and ischemic stroke. World Journal of Emergency Medicine. 2017;8(1):348.

39. An SJ, Kim TJ, Yoon BW. Epidemiology, risk factors, and clinical features of intracerebral hemorrhage: An update. The Journal of Stroke. 2017;19(1):3-10.

40. Krishnan G, Tiwari S, Pai AR, Rao SN. Variability in aphasia following subcortical hemorrhagic lesion. Annals of Neurosciences. 2012;19(4):158-60.

41. Klebic J, Salihovic N, Softic R, Salihovic D. Aphasia disorders outcome after stroke. Medical Archives. 2011;65(5):283-6.

42. Shigematsu K, Nakano $H$, Watanabe $Y$. Speech disturbance at stroke onset is correlated with stroke early mortality. BioMed Central Neurology. 2013;13:87.

43. Lisabeth LD, Brown DL, Hughes R, Majersik JJ, Morgenstern LB. Acute stroke symptoms, comparing women and men. Stroke. 2009;40:2031-6.

44. Boan AD, Lackland DT, Ovbiagele B. Lowering of blood pressure for recurrent stroke prevention: Topical review. Stroke. 2014;45(8):2506-13.

45. Andersen KK, Olsen TS, Dehlendorff C, Kammersgaard LP. Hemorrhagic and ischemic strokes compared, stroke severity, mortality, and risk factors. Stroke. 2009;40:2068-72.

46. Yaghi S, Elkind MSV. Cryptogenic stroke a diagnostic challenge. Neurology. 
2014;4(5):386-93.

47. Keep RF, Hua Y, Xi G. Intracerebral haemorrhage: Mechanisms of injury and therapeutic targets. The Lancet Neurology. 2012;11:720-31.

48. Zia E, Hedblad B, Rasmussen HP, et al. Blood pressure in relation to the incidence of cerebral infarction and intracerebral hemorrhage. Hypertensive hemorrhage: Debated nomenclature is still relevant. Stroke. 2007;38:2681-5.

49. Arboix A. Cardiovascular risk factor for acute stroke: Risk profiles in the different subtypes of ischemic stroke. World Journal of Clinical Cases. 2015;3(5):418-29.

50. Taneja N, Mohan B, Khurana S, Sharma M. Antimicrobial resistance in selected bacterial enteropathogens in north India. The Indian Journal of Medical Research. 2004;120(1):39-43.

51. Hemphill JC, Greenberg SM, Anderson CS, Becker K, Bendok BR, et al. Guidelines for the management of spontaneous intracerebral hemorrhage a guideline for healthcare professionals from the American Heart Association/American Stroke Association. Stroke. 2015;46:2032-60.

52. Gund BM, Jagtap PN, Ingale VB, Patil RY. Stroke: A brain Attack. IOSR Journal of Pharmacy. 2013;3(8):1-23.

53. Kanyal N. The science of ischemic stroke: Pathophysiology Pharmacological treatment. International Journal of Pharma Research \& Review. 2015;4(10):65-84. 